\title{
Control of Bacterial Contamination during Marine Fish Processing
}

\author{
Martha NNNShikongo-Nambabi (Corresponding author) \\ Department of Food Science and Technology, University of Namibia \\ P. Bag 13301, Windhoek, Namibia
}

Tel: 264-61-206-4003E-mail: mnambabi@unam.na

\author{
Abraham Shoolongela \\ Namibia Beverages \\ P.O. Box, 1435, Windhoek, Namibia
}

Tel: 264-61-32-7000 E-mail: ashoolongela@ccsabco.co.za

Martin B Schneider

Faculty of Agriculture and Natural Resources, University of Namibia

P. Bag 13301, Windhoek, Namibia

Tel: 264-61-206-3890Ｅ-mail: mbschneider@unam.na

Received: October, 27, 2011 Accepted: November, 8, 2011

doi:10.5296/jbls.v3i1.1033 URL: http://dx.doi.org/10.5296/jbls.v3i1.1033 


\section{Abstract}

Fish is a vital source of nutrients to humans due to its proteinaceous nature, high content of unsaturated fatty acids and low contents of carbohydrates. In their natural environments fish are exposed to a myriad of microorganisms some of which compromise the shelf life of the product and/or safety in humans. Most fish factories located along coasts find it economical to use processed sea water during processing. Processed sea water however can be a source of microbial contamination to fish. Fish factories are also vulnerable to biofilm formation on surfaces and within water distribution pipes. Biofilms result from bacterial attachment and growth in aqueous environments that render bacteria resistant to sanitising agents. This article reviews the conditions permissible to bacterial contamination in marine fish factories. The role of water in bacterial contamination and survival has been highlighted. Bacterial pathogens commonly associated with fish factories and their survival strategies have also been discussed. The use of selected sanitizing agents and UV irradiation in marine fish processing have been explored. The fundamental antimicrobial mechanisms of chlorine, ozone and $\mathrm{H}_{2} \mathrm{O}_{2}$ is the generation of toxic metabolic intermediates that damage microbial structural and functional components, causing metabolic paralysis and cell death. UV radiation damages DNA hindering gene expression processes. Controlling bacteria biofilm has been well experimented in fresh water systems, but knowledge about disinfection of marine waters is still lacking. The review concludes that in order to optimise the microbiological quality of marine fish, suitable disinfectants effective in sea water need to be authenticated.

Keywords: Biofilms, Fish factories, Sanitation Seafood 


\section{Introduction}

Seafood contamination occurs naturally from the environment where fish are harvested, during harvesting, processing or during food preparation. Cross contamination may occur during food processing or preparation where bacteria are transferred from raw fish and/or contaminated surfaces and/or from utensils to hygienically safe seafood (Wekell et al., 1994). During processing contaminated water may also introduce microorganisms including pathogens into the food. In some cases the levels present in the food may not be critical as to pose a health hazard to consumers. Improper methods of handling (poor general and /or personal hygiene) and distribution (time-temperature abuse) (Wekell et al., 1994) may provide ideal conditions for the pathogens to proliferate and reach infective levels. A number of pathogens belonging to different microbial taxa are predominant in marine environments and find their way into seafood. These include Aeromonas, Plesiomonas, Clostridium botulinum, Listeria monocytogenes and Vibrio species (Wekell et al., 1994). The first line of control of the presence of bacterial pathogens in seafood is the use of Good Manufacturing Processes (GMP) (Vasconcellos, 2004a). Secondly most seafood processors have effective safety and quality assurance systems in place in most cases based on the Hazard Analysis Critical Control Points (HACCP) principles (Vasconcellos, 2004b; Ward, 2002). Several methods to remove, reduce, kill or inhibit the growth of pathogens in seafood and water are employed. One of the main functions of the HACCP system is to ensure the effectiveness and robustness of these methods. Proper sanitation of the food processing environment using the right sanitizers in correct concentrations is paramount to keeping the initial microbial load to the minimum. In addition upholding the personal hygiene of the personnel and training in sanitation methods, as well as the use of potable clean water in all cleaning and sanitation procedures are indispensable in attaining this objective. Once this goal has been achieved other methods to be used in successive steps will be successful in reducing or eliminating spoilage organisms and pathogens to acceptable limits hence attaining the desired shelf life and safety of the final product (Ray and Bhunia 2008). The present work reviews sources of microbial contamination in marine fish factories. The use of oxidising agents most commonly used to ensure fish quality and safety in a marine fish processing environment is explored. The challenges encountered and successes made with their use have been discussed.

\section{The role of water in the processing of marine fish}

When fish are filleted, deboned, packaged and frozen, before distribution, exposure of the fish to water constitutes one of the critical steps that must be optimally controlled in order to prevent the introduction of pathogens. The water used in the processing of fish needs to be clean with minimally acceptable levels of spoilage bacteria and free of pathogens. For this purpose, it is essential that biofilm formation is minimized to ensure optimal microbial quality of the water during distribution and use.

\subsection{Biofilm formation in water distribution systems}

Biofilms are hydrated, (85-95\% water) (Chmielewski\& Frank, 2003) multicellular structures occurring in oligotrophic environments formed through adhesion, growth and metabolism of microorganisms on surfaces. Bacteria in biofilms are covered in complex extracellular 
polymeric substance (EPS) matrix that protect the cells from adverse effects of a changing environment and from antimicrobial agents such as sanitizers, antibiotics and host defence mechanisms (O’ Toole et al., 2000; Costerton 2005; Hall-Stoodley\&Stoodley 2005). Biofilm formation is influenced by a number of environmental factors including nutrient availability (O' Toole et al., 2000), which in water distribution systems may be in a form of biodegradable dissolved organic carbon (BDOC), the water temperature, the concentration of disinfectant and the nature of the surface (Momba et al., 2000). A nutrient rich environment promotes biofilm formation, but cells tend to detach from such structures and favour the free swimming form that enables them to scavenge for nutrients during scarcity ( $\mathrm{O}$ ' Toole et al., 2000).

Once attached cells undergo a series of phenotypic changes emanating from the gene expression level that enable them to adapt to the new environment and to carry out unusual metabolic activities including secretion of exopolysaccharides that render them resistant to disinfectants (O' Toole et al., 2000; reviewed by Prigent-CombaretLejeune, 1999; Langsrud et al., 2003; Whiteley, et al., 2001). Retardation of molecular movement through the biofilm matrix and reduced bacterial growth rates are some of the mechanisms by which resident bacteria mediate resistance to antimicrobial agents (Costerston et al., 1987; Donlan\&Costerton 2002). The EPS may also concentrate nutrients, sequester metals and toxins and protect resident bacteria from desiccation (Chmielewski\& Frank, 2003). Chu et al., (2003) using a laboratory scale continuous flow unit demonstrated that though addition of chlorine to the experimental system reduced the number of colony forming units recovered from biofilms, this disinfection process did not completely inhibit biofilm formation and some bacterial count up to $\log 2 \mathrm{cfu}$ (colony forming units)/g were still detected.

EPS consist of polysaccharides, proteins, phospholipids, teichoic and nucleic acids (Chmielewski\& Frank, 2003). Bacterial biofilms consist of either a single layer of attached cells (Chmielewski\& Frank, 2003) or may be defined three dimensional structures with species specific architectural organisation that may (Lawrence et al., 1987) or may not (Lawrence et al., 1991) consist of microcolonies (flocks or aggregates) (Chmielewki\& Frank, 2003 ) interspersed by water channels. The architecture of a mature biofilm depends on the hydrodynamics of the surrounding fluid (Chmielewski\& Frank, 2003).

\subsection{Bacterial pathogens in biofilms}

Some bacteria are able to form biofilms in isolation while others establish synergistic associations termed co-aggregates, in which one organism acts as a primary attachment candidate and exopolysaccharide producer providing a favourable environment and protection for the other species (Palmer et al., 2007). In biofilms bacterial pathogens can form part of biofilms and pose a challenge to public health and food shelf life as well as safety e.g. Table 1. Biofilms provide a favourable microenvironment for pathogens and act as stable sources of large number of pathogens while the flow of water facilitates pathogens dispersal in a form of clumps or clusters (Hall-Stoodley\&Stoodley, 2005). Biofilms, therefore, confer a selective advantage to pathogens by enabling them to persist, multiply and disseminate (Hall-Stoodley\&Stoodley, 2005). It is also assumed that the first prokaryotic cells had the 
propensity to exist in biofilms as the natural stable structures and that free swimming cells evolved for the sake of dispersal in environments (McDougal \&Kjellberg, 2006). The ability of the pathogens to grow and form biofilms in vitro depends on the nature of the surface; rough surfaces are more difficult to clean properly hence favour biofilm formation, on the composition of the growth medium, on genetic factors and the environmental conditions. Variations within individual strains of the same species in their ability to form biofilms are also common (Reisner et al., 2006).

A number of Vibrios including pathogenic species V. cholerae (Faruque et al., 2006), V. parahaemolyticus (Enos-Berlage et al., 2005), V. vulnificus (Joseph \& Wright, 2004) and V. alginolyticus (Kogure et al., 1998) are able to form biofilms. V. cholerae, one of the most prevalent human pathogenic Vibrio species has been shown to form biofilms on both biotic and abiotic surfaces (Mueller et al., 2007). Bacterial attachment to surfaces improves their survival potential, and transmission in a hostile environment. Mueller et al., (2007) demonstrated 30 gene loci in $V$. cholerae that are involved in biofilm formation in addition to the mannose sensitive haemagglutinin factor Type IV pilus. However there is high genetic and phenotypic variability among different strains in their requirements for surface attachment. Enos-Berlage et al., (2005) demonstrated that both opaque and translucent colonies of $V$. parahaemolyticus form biofilms in micro titre plates. $V$. alginolyticus formation of biofilms is mediated by the $\mathrm{Na}^{+}$dependent polar flagellum (Kogure et al., 1998). Joseph \& Wright, (2004) showed that capsular polysaccharides (CPS) inhibit biofilm formation by $V$. vulnificus and that the polysaccharides differ from those of $V$. cholerae in chemical composition that affect the net surface charge being highly negative in $V$. vulnificus CPS.

Table 1.Bacterial pathogens well known to form biofilms

\begin{tabular}{|l|l|}
\hline Bacterial species & Reference \\
\hline Pseudomonas aeruginosa & (Dewanti et al.,1995; Banning et al., 2003; Reisner et al., 2006 \\
\hline E.coli & (Dewanti et al, 1995; Banning et al., 2003; Reisner et al., 2006 \\
\hline Vibrio cholerae & Mueller et al., 2007 \\
\hline Vibrio parahaemolyticus & Enos-Berlage et al., 2005 \\
\hline Listeria monocytogenes & Kim \& Frank 1995 \\
\hline Legionella pneumophila & Armon et al., 1997; Carvalho et al., 2007; Marao et al., 1993 \\
\hline E. coli & Reisner et al., 2006 \\
\hline Salmonella & Chmielewski\& Frank 2003 \\
\hline Campylobacter jejuni & Buswell et al., 1999 \\
\hline Helicobacter pylori & Mackay et al., 1999 \\
\hline
\end{tabular}

\section{Control of biofilm formation in water used for fish processing}

Biofilm control entails prevention of biofilm formation by suspended microorganisms and removal of matured biofilms from food processing equipment, from inside the water pipes and from medical equipment. Various disinfectants have been used in food processing plants including ultraviolet light, potassium permanganate, bromine, hydrogen peroxide, 
permonosulphuric acid, ozone and chlorine (Degrèmont, 1991).

\subsection{Chlorination of water used for fish processing}

Chlorine compounds are broad spectrum antimicrobials, active against vegetative forms of bacteria, fungi, spores, and viruses (Ray, 2003). Chlorine act by oxidising sulfhydryl (-SH) groups of enzymes and structural proteins, by causing damage to cell membrane, by disrupting protein synthesis, by reacting with nucleic acids hence interfering with total cell metabolism (Ray, 2003). Liquid chlorine and hypochlorites carry out their germicidal activity through formation of hypochlorous acid $(\mathrm{HOCl})$ that is most potent at acidic $\mathrm{pH}$ due to its oxidising power the smaller molecular weight and electrical neutrality. In solution at $\mathrm{pH}$ above neutrality and ambient temperatures $\mathrm{HOCl}$ becomes less effective as it dissociates into $\mathrm{H}^{+}$and hypochlorite anions $\left(\mathrm{OCl}^{-}\right)$. The $\mathrm{OCl}^{-}$is less effective as its negative charge seems to interfere with cell penetration (Walker, 1978).

Different forms of chlorine are used as disinfectants, (Sodium hypochlorite) liquid chlorine, chlorine gas $\left(\mathrm{Cl}_{2}\right)$, hypochlorites (salt) $(\mathrm{CaOHCl})$, organic and inorganic chloramines and chlorine dioxide (Mombaet al., 2002; Ray, 2003). In fish processing only chlorine gas and hypochlorite solutions are typically used (Bonnell, 1994). Three components are important in chlorination regimes; chlorine dosage (amount of chlorine added), chlorine demand (amount of chlorine that reacts with impurities in water), and total residual chlorine (total amounts of chlorine that remains loosely combined with nitrogenous compound and the free amounts of chlorine that remains available to kill microorganisms) (LeChevallier\& Au, 2004). The recommended level of free residual chlorine is 5-7 ppm for fish processing water and 15-25 ppm for surface cleaning (Bonnell, 1994). Residual chlorine should have a retention time of at least 20-30 minutes (LeChevallier\& $\mathrm{Au}, 2004$ ). When sea water, brine or brackish water is readily available a self containedhypochlorinator that generates $\mathrm{NaHOCl}$ through the decomposition of sea water or sodium chloride solution is often more economical for disinfection and the addition of liquid chlorine is not necessary (Walker, 1978). Chlorine concentration decreases in disinfected fresh water systems due to a natural decay related to the chlorine reacting with the pipe wall itself and the bulk decay which is the water chlorine demand (Mombaet al., 2002). In these systems the use of chloramines for disinfection is gaining popularity of over chlorine because chloramines generate less toxic compounds and could be safely used in high dosage to prevent development of bad tastes. Chloramines also have a longer half-life in water than chlorine especially in waters with high content of organic matter (Mombaet al., 2002; Momba\&Binda, 2002).

Chlorine compounds suffer several disadvantages; they are less effective in the presence of organic matter and in hard water, less stable at higher temperatures, corrosive to metals, and can cause discolouration of food through lipid oxidation (Ray, 2003). The use of chlorine and its derivatives is also associated with the formation of toxic and possibly carcinogenic compounds commonly referred to as disinfection by products e.g. trihalomethanes (THM), bromate, haloacetonitriles, and haloacetic acid (HAA) formed when chlorine reacts with organic compounds naturally found in water (LeChevallier\& Au, 2004; Gopalet al., 2007; Wang et al., 2007). Shikongo-Nambabi et al., (2010) showed that chlorine was ineffective in 
controlling biofilm formation by $V$. alginolyticus and $V$. parahaemolyticus LMG2850 strains in sea water. Chloramines are week disinfectants and less effective against protozoa, bacteria and viruses hence mostly used as secondary disinfectants. Chloramines also produce volatile compounds that impart undesirable taste and odour (Mombaet al., 2002; Gopalet al., 2007).

\subsection{The use of UV irradiation in food processing}

The UV light occupies the 40-400 $\mathrm{nm}$ region of the electromagnetic spectrum (LeChevallier\& $\mathrm{Au}, 2004)$. It is produced using low pressure or high pressure mercury vapour lamps. The disinfection system normally consists of a mercury vapour lamp surrounded by a protective coat such as quartz. The device is inserted into a tube or cylinder or can be used in a tank connected to the water supply. In the cylindrical form the water to be disinfected is passed over the UV lamp where the water rapidly absorbs the radiation as it flows past the lamp (Mahapatraet al., 2005).

UV light causes damage to the DNA by cross linking the thymidine bases through a double bond forming dimmers that inhibits DNA replication and translation (LeChevallier\& $\mathrm{Au}$, 2004). The cytoplasmic membrane is also affected (Mahapatraet al., 2005). Some microorganisms are able to repair damaged DNA by photoreactivation in the presence of light and dark repair in the absence of light. The repair mechanisms compromise the action of the UV light, high doses are therefore necessary to ensure that the process of microbial inactivation has been done beyond repair (Lechevallier\& $\mathrm{Au}, 2004)$. UV action is not long lasting due to the lack of a residual effect (Degremont, 1991). Bacterial are more sensitive to UV light than viruses and are killed by exposure to $0.65-31 \mathrm{~mW}-\mathrm{sec} / \mathrm{cm}^{2}$. V. cholerae is highly sensitive, a 4-log reduction is attained by exposure to $0.65 \mathrm{~mW}-\mathrm{sec} / \mathrm{cm}^{2}$. Spores of Gram positive bacteria are most resistant; a 4-log reduction can be effected by exposure to 31 $\mathrm{mW}$-sec/ $\mathrm{cm}^{2}$ (LeChevallier\& Au 2004). The use of UV irradiation in fish processing facilities has not been documented.

\subsection{The use of ozone on food processing}

Ozone is an allotrope of oxygen that contains three oxygen molecules $\left(\mathrm{O}_{3}\right)$ (Degremont, 1991). Ozone acts by oxidising microbial cells due to its high positive oxidising potential (+0.27 V) (Mahapatraet al., 2005). Ozone has antibacterial, antifungal, and antiviral properties (Khadre et al, 2001). The primary target of ozone is the bacterial cell surface. Once in contact with the cell surface its oxidising activity causes damage of essential components in the cell membrane through damage to the double bond in unsaturated fatty acids, the lipoproteins and lipopolysaccharides in the cell wall of Gram negative bacteria by reactive oxygen species. It also damages glycolipids, glycoproteins and nucleic acids present in the cell membrane causing flocculation of cellular proteins, interference with the respiratory system, oxidation of the sulfhydryl groups to form disulfide bonds and damage to DNA primarily of the pyrimidine bases and eventually leakage of cytoplasmic contents (Kim et al., 1999; Guzel-Seydimet al., 2004). Ozone causes oxidation of amino acids of proteins, enzymes and peptides to shorter peptides; polyunsaturated fatty acids are oxidised to acid peroxides (Guzel-Seydimet al., 2004). Ozone is effective against a wide range of both Gram positive and Gram negative bacteria in both vegetative and spore forms including E. coli, 
Pseudomonaputrefaciens, Salmonella, St. aureus, L. monocytogenes at concentrations of 0.05-2 mg/l; against fungi and fungal spores at concentrations of $6-9 \mathrm{mg} / \mathrm{l}$, and against viruses at concentrations of $600 \mathrm{mg} / \mathrm{l}$. It is also effective against bacterial endospores when the relative humidity of the treatment medium is increased to $50 \%$ (Kim et al., 1999; GuzelSeydimet al., 2004; Mahapatraet al., 2005). In Gram negative bacteria the lipoprotein and lipopolysacharides are particularly susceptible (Guzel-Seydimet al., 2004).

However, the effectiveness of ozone depends of the presence of suspended organic particle and on the $\mathrm{pH}$ of the medium. Acidic $\mathrm{pH}$ values enhance the lethality of ozone (Kim et al., 1999). In water treatment ozone demand increases as the amount of suspended particles and pH increase (Kim et al., 1999). Ozone is used as sanitizer of food surfaces for many foods; cheese, eggs, poultry, fruits and vegetables, and fish (Kim et al., 1999) mostly with positive results in extending the shelf life of products and improving the sensory quality such as the colour of fish products. Although ozone was more effective than chlorine and inhibited biofilms formation by certain strains of $V$. alginolyticusin sea water at $1.6 \mathrm{mg} / \mathrm{land} 0.8 \mathrm{mg} / \mathrm{l}$ the potency of ozone was found to be limited and could not inhibit biofilms formation by a different strain of $V$. alginolyticus and by $V$. parahaemolyticus type strain LMG 2850 at 2.0 $\mathrm{mg} / \mathrm{l}$. In the same environment ozone was able to reduce mature biofilms formed by the four tested Vibrio strains only by 1 log up to $2 \mathrm{mg} / \mathrm{l}$ (Shikongo-Nambabi et al., 2010).

There are three methods for producing ozone. The most widely used method is the electrical discharge method. Dried clean air or oxygen at dew point $\left(-60^{\circ} \mathrm{C}\right.$ to $\left.-80^{\circ} \mathrm{C}\right)$ (Degremont, 1991) is passed through two high voltage electrodes, also called a corona, ozonator, or plasma. The electrodes are in a form of either concentric rings or parallel plates (Degremont, 1991; Mahapatraet al., 2005; Chawla 2006; Degremont 2007). The high voltage (15,000-20,000 Volts) (Walker, 1978; Guzel-Seydim, et al., 2004) electrical discharge in the form of an alternating current is passed through a small gap (Degremont, 1991; Fielding\& Bailey, 2005; Chawla, 2006) between the electrodes where the air or gas containing oxygen is present. This high electrical field causes electron excitation and the formation of unstable oxygen radicals $\left(\mathrm{O}^{-}\right)$, which spontaneously combine with intact oxygen molecules to form Ozone $\left(\mathrm{O}_{3}\right)$ (Degremont, 1991; Mahapatraet al., 2005). Ozone could also be produced by the electrochemical method or when using ultraviolet light with a wavelength of $185 \mathrm{~nm}$ (Fielding \&Bailey, 2005).

In the USA, ozone received the generally regarded as safe (GRAS) status from the FDA in 2001 and could now be used in both gaseous and aqueous form for food processing and preservation (Guzel-Seydimet al., 2004; Mahapatraet al., 2005). Ozone, is therefore, used as a direct decontaminant on both food surfaces and equipment. Several studies have demonstrated the effectiveness of ozone as a decontaminant in the food processing environments. It was successfully used in the decontamination of equipment and food contact surfaces in a cheese processing factory. Both the aerobic plate count and the level of Enterobacteriaceae were reduced over a period of two months after exposure of the whole plant to $2 \mathrm{mg} / \mathrm{l}$ ozone overnight. When the treatment with ozone was discontinued the levels of theEnterobacteriaceae and total counts returned to unacceptable levels (Fielding and Bailey 2005). It was also used in disinfection of poultry chill water and carcasses, in treating 
fruits and vegetables to reduce microbial load including moulds and to increase the shelf-life (reviewed, by Kim et al., 1999; Guzel-Seydimet al.,2004).

Ozone is more effective in low ozone demand liquid media than on food surfaces. The composition of the food surface, the type of microbial contaminant and the degree of association of the microorganisms dictate the effectiveness of ozone. Higher moisture content in food promotes ozone action. It has been proved to significantly reduce counts of Clostridia, Pseudomonas, Salmonella, Staphylococcus and fungi at > 2mg/l (Kim et al., 1999).

In all experiments conducted ozone caused significant improvement in food quality and hygiene by either lowering the microbial load or by improving the shelf life or taste of the food products. Dew, (2005) demonstrated that off flavours caused by methylisoboneol on catfish could be reduced when fillets from fresh catfish spiked and stored for 12 hours were treated with ozone for 30-60 minutes. Overall ozone has no effect on chemical and sensory properties of foods, except on dry foods where a decrease in essential oils and a negative sensory quality of spices was experienced (Kim et al, 1999). The use of ozone in food preservation has now been patented for spices, herbs, fruits, vegetables, fish, beef, and for food process water (Kim et al., 1999).

Lower concentrations and shorter contact time of ozone are required in food, food plant, and water sanitation than chlorine (Kim et al., 1999). Unlike chlorine that leaves potential carcinogens in the environment such as trihalomethanes (THM) and haloacetic acids (HAA) (Guzel-Seydimet al., 2004; Guzel-Seydimet al., 2004; Chawla, 2006), ozone does not leave any residues hence it is ideal for use as a terminal sanitizer of food surfaces and process water in industries. Also, unlike chlorine where continuous use of high amounts may trigger development of resistance in some bacteria and viruses, ozone reacts quickly killing microorganisms, hence giving them no chance to develop resistance (Chawla, 2006). Ozone has been shown to effectively remove biofilms where other disinfectants have failed (Fielding \& Bailey 2005). Ozone also removes bad tastes, odours and colour in water. It is more effective than trisodium phosphate and acetic acid, but comparable to $\mathrm{H}_{2} \mathrm{O}_{2}$ at lower concentrations (Fielding \& Bailey 2005).

Ozone has low solubility in water, thus proper mixing and high doses are required to attain optimum efficiency (Walker, 1978). Ozone is highly reactive thus it reacts with any organic materials including textiles, organic dyes, metals, plastic, paint, and natural rubber, but this side effect can be reduced by the addition of antiozonants (Fielding \& Bailey 2005). It is, however, not more corrosive than chlorine. The short half life of ozone necessitates that it is used together with other disinfectants if a residual disinfectant is required to inhibit biofilm formation within water distribution networks (Chawla, 2006). If not handled correctly ozone could impact on human health. Doses of $0.1 \mathrm{mg} / \mathrm{l}$ can cause sharp irritation of the nose and throat, $0.1-0.5 \mathrm{mg} / \mathrm{l}$ exposure for 6 hours can result into loss of vision. At 1-2 mg/l ozone could cause headaches, dizziness, weakness, decreased memory and other symptoms associated with irritation of the upper respiratory tract, while high doses $(5-10 \mathrm{mg} / \mathrm{l})$ and $50 \mathrm{mg} / \mathrm{l}$ or more could cause oedema of the lungs and death respectively (Guzel-Seydimet al., 2004; Mahapatraet al., 2005). The Occupational Safety and Health Administration (OSHA), 
USA has set limits for ozone exposure as $0.01-0.05 \mathrm{mg} / \mathrm{l}$ for detectable odour and $0.1 \mathrm{mg} / \mathrm{l}$ as exposure limit over an 8 hour period (Mahapatraet al., 2005).

\subsection{Use of Hydrogen peroxide in food sanitation}

Hydrogen peroxide is a chemical compound that contains two atoms of hydrogen and two atoms of oxygen $\left(\mathrm{H}_{2} \mathrm{O}_{2}\right)$. The compound is produced naturally by certain bacteria including Pediococcus, Lactobacillus and Streptococcus. pneumonia or in media exposed to light and oxygen causing inhibition on other bacterial species (Juven\& Pierson 1996; Periconeet al., 2000). It is also produced photosynthetically in Cyanobacteria and in plants (Roncelet al., 1989). Gaseous $\mathrm{H}_{2} \mathrm{O}_{2}$ is produced naturally by photochemical reactions in the atmosphere, but is also produced artificially by dissolving barium peroxide in water (Schumbet al., 1955).

$\mathrm{H}_{2} \mathrm{O}_{2}$ has a wide range of house hold and industrial applications; as a food preservative (Brul\&Coote, 1999; Juven\& Pierson, 1996) and, in industrial and drinking water dechlorination (Worley, 2000). $\mathrm{H}_{2} \mathrm{O}_{2}$ is used to control biofouling and other pollutants in drinking water, soil, air and in waste water distribution systems; to remove, sulphides, metals and other easily oxidisable materials (solids, gasoline and pesticides) and industrial solvents; for detoxification and deodourisation and for cosmetics and laundry applications (Asano et al., 2007; Degremont, 2007). The combinations of $\mathrm{H}_{2} \mathrm{O}_{2}$ with ozone (peroxones) and with UV light are used for ground water, drinking water, and waste water disinfection (Lenntech,2011 http://www.lenntech.com/processes/disinfection/chemical/disinfectants-hydrogen-peroxide.ht $\mathrm{m}$ ). In industries concentrations of 30-50\% are generally used as sanitising agents (Co-op, 2008http://www.h2o2-4u.com/grades.html. Accessed 10/27/2008). It is also used in combination with other additives such as potassium sorbate. It is used to sterilise containers for aseptic packaging (Juven\& Pierson, 1996; Lück\&Jager, 1997). In low concentrations (0.02 and $0.05 \%) \mathrm{H}_{2} \mathrm{O}_{2}$ was used to kill pathogens and spoilage bacteria during the pre-Pasteurisation era and it is still used in the USA to preserve cheese and milk (Lück\&Jager, 1997) but this practice presents a drawback due to the peroxide damage to vitamins. $\mathrm{H}_{2} \mathrm{O}_{2}$ is used for sanitising hatching eggs and to sterilise liquid whole egg (Juven\& Pierson, 1996). The residual $\mathrm{H}_{2} \mathrm{O}_{2}$ is normally inactivated by addition of catalase (Lück\&Jager, 1997). However $\mathrm{H}_{2} \mathrm{O}_{2}$ is not recommended in swimming pool disinfection unless when used in combination with other disinfectants (UV, ozone, silver salts, or quaternary ammonium compounds). In this respect it is therefore assumed to be less effective than chlorine, bromine and ozone. It was recommended for Anthrax spores decontamination after the 2001 bioterrorism attack on USA (EPA, 2007http://www.epa.gov/pesticides/factsheets/chemicals/hydrogenperoxide/).http://www.epa.go v/pesticides/factsheets/chemicals/hydrogenperoxide/ It can be used as surface decontaminant in either aqueous or vapour forms (Juven\& Pierson 1996).

Lillard\& Thomson, (1983) showed that 5,300 - 12,000 mg/l $\mathrm{H}_{2} \mathrm{O}_{2}$ reduced aerobic counts and E coli in water by 95-99\%. Kim \& Day, (2007) reported that a combination of $\mathrm{H}_{2} \mathrm{O}_{2}$ with sodium bisulfide and thymol was effective in removing attached $E$. coli and SalmonellaTyphimurium from chicken carcasses. Droguiet al., (2001) have demonstrated that electroperoxidation removed dissolved organic carbon from solutions of phenol, salicylic 
acid, benzoic, and humic acids. $\mathrm{H}_{2} \mathrm{O}_{2}$ completely inhibited biofilm initiation and destroyed mature biofilms in sea water at $0.05 \%$ and $0.2 \%$ respectively formed by four different Vibrio species strains and was hence recommended as the possible biocide of choice in marine fish processing facilities (Shikongo-Nambabi et al., 2010).

$\mathrm{H}_{2} \mathrm{O}_{2}$ is a strong oxidising agent due to its ability to generate extremely biocidal reactive oxygen and hydroxyl radicals $\left(\mathrm{O}^{-}, \mathrm{OH}^{-}\right)$(Brul\&Coote 1999; Sias, 2003http://www.cemag.us/articles.asp?pid=238). In the presence of superoxide radical $\left(\mathrm{O}_{2}{ }^{2-}\right)$ and transition metal ions such as $\left.\mathrm{Fe}^{2+}\right) \mathrm{H}_{2} \mathrm{O}_{2}$ forms hydroxyl radical $\left(\mathrm{OH}^{-}\right)$by the Fenton like and Haber-Weiss reactions respectively (Juven\& Pierson 1996; Watts et al., 1999). Secondly, the lactoperoxidase system naturally occurring in milk and other biological fluids produces hypothiocyanate $\left(\mathrm{OSCN}^{-}\right)$through the oxidation of the thiocyanate ion $\left(\mathrm{SCN}^{-}\right)$by $\mathrm{H}_{2} \mathrm{O}_{2}$ (Juven\& Pierson, 1996). The free hydroxyl radicals and singlet oxygen produced attack microbial cells causing irreversible damage to essential cell components including membrane lipids, DNA, and enzymes (Lück\&Jager, 1997; Brul\&Coote, 1999). $\mathrm{H}_{2} \mathrm{O}_{2}$ is a more powerful oxidising agent than chlorine, chlorine dioxide and potassium permanganate; it has a lower oxidation potential than ozone, hydroxyl radical, and fluorine (Lück\&Jager, 1997).

The antimicrobial action of $\mathrm{H}_{2} \mathrm{O}_{2}$ is temperature and $\mathrm{pH}$ dependent (Brul\&Coote, 1999) and it is potentiated by reducing agents such as peroxidases (Juven\& Pierson, 1996). At low concentrations $\mathrm{H}_{2} \mathrm{O}_{2}$ is more effective against bacteria, while yeasts and moulds require higher concentrations. In solution it enhances the antimicrobial effect of heat against vegetative cells and spores (Lück\&Jager, 1997).

In water the free oxygen radicals decompose pollutants, while the $\mathrm{H}_{2} \mathrm{O}_{2}$ molecule is reduced to oxygen and water (Lenntech, 2011 http://www.lenntech.com/processes/disinfection/chemical/disinfectants-hydrogen-peroxide.ht $\mathrm{m})$. On food surfaces in the presence of organic material hydrogen peroxide decomposes completely forming water and oxygen, hence does not leave any undesirable or toxic chemical residues; decomposition is enhanced by the presence of pollutants and high temperatures (Lück\&Jager 1997). $\mathrm{H}_{2} \mathrm{O}_{2}$ is, however, highly corrosive reacting with a number of substances

(Lenntech

2011http://www.lenntech.com/processes/disinfection/chemical/disinfectants-hydrogen-peroxi de.htm). Human exposure to damp or mist can cause irritation of the eyes, skin, and mucous membranes. Concentrations of $5 \%$ or more can cause permanent eye damage; contact with skin causes painful blisters, burns and skin whitening. "Organs most susceptible to $\mathrm{H}_{2} \mathrm{O}_{2}$ exposure are the lungs, intestines, and thymus"(Lenntech, 2011http://www.lenntech.com/processes/disinfection/chemical/disinfectants-hydrogen-peroxi de.htm). Tests done on laboratory animals show that $\mathrm{H}_{2} \mathrm{O}_{2}$ is a potent carcinogen; it has also been shown to cause mutations in bacteria through damage to DNA (Lenntech, 2011 http://www.lenntech.com/processes/disinfection/chemical/disinfectants-hydrogen-peroxide.ht m). $\mathrm{H}_{2} \mathrm{O}_{2}$ reacts with food constituents such as vitamins and has a bleaching effect. $\mathrm{H}_{2} \mathrm{O}_{2}$ is used to bleach starch, gelatine, and fish marinades to suppress bacterial spoilage and odours in some countries (Lück\&Jager 1997). Although the use of hydrogen peroxide is not regulated under the EU legislation $98 / 83 / \mathrm{EC}$, in the $\mathrm{USA}_{2} \mathrm{O}_{2}$ was registered as a pesticide 
by Environmental Protection Agency (EPA) in 1977 hence used directly on dairy/cheese processing plants, on eggs, as a decontaminant of packaging materials, in agricultural premises, medical facilities, home bathrooms, on food processing equipment, and as Pasteurisers in breweries, wineries, and beverage plants (Brul\&Coote, 1999; EPA, 2007http://www.epa.gov/pesticides/factsheets/chemicals/hydrogenperoxide_peroxiaceticacid; Lenntech,2011http://www.lenntech.com/processes/disinfection/chemical/disinfectants-hydrog en-peroxide.htm).错误！超链接引用无效。

\section{Conclusion}

Bacterial contamination is of paramount importance to the safety and shelf life of processed food. To optimise the microbiological quality of food, it is important to implement acceptable good manufacturing practices through adequate temperature control and training of personnel. Recommended training includes personal hygiene, a sound HACCP system, and the use of clean and hygienically controlled equipment, utensils and materials including water used during processing.

Microorganisms are also constantly changing to adapt to hostile environments created by processing, preservation and sanitation methods. One of such adaptation strategies is attachment of bacteria to water distribution pipes and food processing surfaces, forming single or multispecies layers of three dimensional structures covered in matrices with limited permeability to chemical substances used in sanitation. Within biofilms, bacteria undergo a series of genetic and phenotypic changes as means of adaptations that often leads to selection for virulent strains. In most cases bacteria in biofilms exhibit adaptive traits such as increased ability to attach to surfaces and secretions of exopolysaccharides. These biofilms act as nodes of water and product recontamination and a mode of pathogens persistence and dispersal in treated water and may compromise product microbiological quality leading to microbial transmission to consumers, resulting into either incidences of food poisoning or outbreak of epidemics. Sea water is abundant and readily available to the marine fish industries around the world. Most factories make use of sea water at one or more steps during processing. Although the water is subjected to conventional water treatment regimes, using mostly chorine and UV irradiation as the method of sanitation, these disinfectants may prove ineffective in controlling spoilage and pathogenic bacteria especially those that are able to attach to surfaces forming biofilms resulting into water recontamination and final product quality deterioration.

The most commonly used disinfectants, in the fishing industry are associated with a number of disadvantages. Chlorine is ineffective in providing proper control and can form substances that are believed to be hazardous to human health and the environment. The UV radiation has low penetrability and it lacks long term effect. Novel disinfection methods such as the use of ozone and $\mathrm{H}_{2} \mathrm{O}_{2}$ for biofilm control therefore need to be explored so as to improve the microbial quality and safety of marine fish. Both ozone and hydrogen peroxide are strong oxidising agents without toxic residues and act instantaneously causing irreversible damage to microbial cell surface and cytoplasmic constituents. They are more potent than chlorine, economical and easily accessible. They are used in many parts of the world in 
decontamination of food processing environments and in improving the shelf life of a wide range of food items through controlling both suspended and sessile microorganisms. Trial studies therefore need to be conducted in assessing the benefits that the fishing industry might reap by using these disinfectants.

\section{Acknowledgement}

The research is financed by the Ministry of Education, Windhoek, Republic of Namibia through the Africa American Institute. We thank the University of Namibia for providing access to research funds and for other logistical assistance through its staff development programme.

\section{References}

Armon, R, Starosvetzky, J, Arbel, T, Green, M.(1997). Survival of Legionella pneumophila and Salmonella typhimurium in biofilm systems. Water Science and Technology, 35, 293-300.

Asano, T., Burton, F.,Leverenz, H.L.,Tsuchihashi, R., \&Tchobanoglous, G.(2007).Water Reuse technologies and Treatment Systems: An Overview.InWaterReuse.Issues, Technologies, and Applications.Technologies and Systems for Water Reclamation and ReusePart 3(pp 255-294). New York: Metcalfe \& Eddy AECOM, McGraw Hill.

Banning, N., Toze, S.,\&Mee, B. J.(2003). Persistence of biofilm associated Escherichia coli and Pseudomonas aeruginosa in groundwater and treated effluent in a laboratory model system. Microbiology. 149(1) 47-55.http://dx.doi.org/10.1099/mic.0.25938-0

Bonnell, A. D.(1994). Sanitation.InQuality Assurance in Seafood Processing. A Practical Guide(pp. 77-89). London: Chapman and Hall.

Brul, S., \&Coote, P. (1999).Preservative agents in foods.Mode of action and microbial resistance mechanisms.International Journal of Food Microbiology, 50(1-2), 1-17. Retrieved from http://www.ncbi.nlm.nih.gov/pubmed/10488839

Buswell, C. M., Herlihy, M., Keevil, C. W., March, R. D., \&Leach, S. A.(1999). Carbon load in aquatic ecosystems affects the diversity and biomass of water biofilm consortia and the persistence of the pathogen Campylobacter jejuni within them. Journal of Applied Microbiology, 85, 161S-167S.http://dx.doi.org/10.1111/j.1365-2672.1998.tb05295.x

Carvalho, F. R. S., Foronda, A. S., \&Pellizari V. H.(2007). Detection of Legionella pneumophila in water and biofilm samples by culture and molecular methods from man-made systems in Sáo Paulo- Brazil. Brazilian Journal of Microbiology.38, 743-751.

Chawla, A. S.(2006). Application of Ozonated water Technology for Improving Quality and Safety of Peeled Shrimp Meat.(M ScThesis) Louisiana State University and Agricultural and Mechanical College, USA.

Chmielewsky, R. A. N., \&Frank, J.F.(2003). Biofilm Formation and Control in Food Processing facilities. Comprehensive Reviews in Food Science and Food Safety.2, 22-31.

Chu, C., Lu, C., Lee, C, \&Tsai C.(2003).Effects of chlorine on the growth of Biofilm in Water Pipes.Journal of Environmental. Science and Health. A38 (7), 1377-1388. http://dx.doi.org/10.1081/ESE-120021132

Clyde Co-Op.(2008).Food Grade vs technical grade Hydrogen Peroxide.Clyde Co-op. [Online]: Retrieved October 27, 2008 from http://www.h2o2-4u.com/grades.html. 
Costerton, J. W., Chen, K.-J., Gees, G. G., Ladd, T.I., Nickel, J. C., Dasgupta, M., \&Marrie, T. J.(1987). Bacteria biofilms in Nature and Disease.AnnualReviews inMicrobiology. 41, 435-464.

Costerton, J. W.(2005). Biofilm theory can guide the treatment of device related orthopaedic infection. Clinical and Orthopaedic Related Research. 437, 7-11.

Degrèmont, S. A.(1991). Oxidation-Disinfection.In Water Treatment Handbook. Volume 2 $\left(6^{\text {th }}\right.$ ed)(pp 873-914). Paris: Lavoisier Publishing.

Degremont, S. A.(2007). Oxidation-Disinfection Other Oxidation and disinfection processes. InWater Ttreatment Handbook. Volume 2 (7th ed.) (pp 1113-1184) Paris: LavoisierPublishing.

Dewanti, R., \&Wong, A. C.(1995). Influence of culture conditions on biofilm formation by $E$. coli O157:H7. International Journal of Food Microbiology. 26 (2), 147-164.

Dew, T. L.(2005). Ozone degradation of Off-Flavours in catfish.(M. Sc. Thesis). Department of Food Science, B. S., Xavier University of Louisiana, USA.

Donlan,R. M.,\&Costerton, J. W.(2002). Biofilms: Survival mechanisms of clinically relevant $\begin{array}{llll}\text { microorganisms. } & \text { Clinical } & \text { Microbiology } & \text { Reviews, }\end{array}$ 167-193.http://dx.doi.org/10.1128/CMR.15.2

Drogui, P., Elmaleh, S., Rumeau, M., Bernard, C.,\&Rambaud, A.(2001). Oxidising and Disinfecting By Hydrogen Peroxide Produced in A Two -Electrode Cell. Water Research. 35 (13), 3235-3241.

Enos-Berlage, J. L., Guvener, Z. T., Keenan, C., \&McCarter, L.L.(2005).Genetic determinants of biofilm development of opaque and translucent VibrioparahaemolyticusMolecular Microbiology. 55(4),1160-1182.http://dx.doi.org/10:19.1111/j.1365.2958.20004.04453x

EPA.(2007). Anthrax spore decontamination using hydrogen proxide and peroacetic acid Pesticides: Topical \& Chemical fact Sheets. National Pesticide Information Center (NPIC). USEPA Web. [Online]: Retrieved August 29, 2008, from http://www.epa.gov/pesticides/factsheets/chemicals/hydrogenperoxide_peroxiaceticacid.

Faruque, S. M., Biswas, K., Udden, S. M. N., Ahma, Q. S., Sack, D. A., Nair, G. B., \&Makalanos, J. J.(2006). Transmissibility of cholera: In vivo-formed biofilms and their relationship to infectivity and persistence in the environment. PNAS 103 (16), 6350-6355.

Fielding, L., \&Bailey, R.(2006). Ozone decontamination in hygiene management InH. L. M.Lelieveld, M. A.Moster,t\&J.Holah (eds.). Handbook of hygiene control in the Food Industry. (pp 507-515). Cambridge. CRC Press, Woodhead Publishing.

Gopal, K., Tripathy, S. S., Bersillon. J. L., \&Dubey, S. P.(2007). Chlorination byproducts, their toxicodynamics and removal from drinking water.Journal Hazardous Materials. 140(1-2),1-6.

Guzel-Seydim, Z. B., Greene, A. K., Seydim, C. A.(2004).Use of Ozone in the Food Industry.Lebensm-Wiss U-Technology. 3, 453-460.

Hall-Stoodley, L.,\&Stoodley, P.(2005).Biofilm formation and dispersal and the transmission of human pathogens.Trends in Microbiology. 13 (1), 7-10.http://dx.doi.org/10.1016/j.tim.2004.11.004

Joseph, L. A., \&Wright, A. C.(2004). Expression of Vibriovulnificus Capsular polysaccharide 
$\begin{array}{llllll}\text { Inhibits Biofilm formation.Journal of } & \text { Bacteriology. } 186 & \text { (3), 889-893. }\end{array}$ http://dx.doi.org/10.1128/JB.186.3.889-893.2004

Juven, B. J., \&Pierson, M. D.(1996). Antibacterial effects of Hydrogen Peroxide and Methods for its Detection and Quantitation.Journal of Food Protection. 59 (11), 1233-1241.

Khadre, M. A. Yousef, A. E., \&Kim, J.-G. (2001). Microbiological Aspects of Ozone Applications in Food: A Review. Journal of FoodScience. 66 (9), 1242-1252.http://dx.doi.org/ 10.1111/j.1365-2621.2001.tb15196.x

Kim, D., \&Day, D. F.(2007).A biocidal combination capable of sanitizing rawchicken skin.Food Control. 18 (10), 1272-1276.

Kim, K. Y., \&Frank, J. F.(1995).Effect of nutrients on biofilm formation by Listeria monocytogenson stainless steel.Journal of Food Protection. 58 (1), 24-28.

Kim, J.-G., Yousef, A. E., \&Davis, S.(1999). Application of Ozone for Enhancing the Microbiological Safety and Quality of Foods.A Review.Journal of Food Protection. 62 (9), 1071-1087.

Kogure, K., Ikemoto, E., \&Morisaki, H.(1998). Attachment of Vibrioalginolyticusto Glass Surfaces Is Dependent On Swimming Speed. Journal of Bacteriology. 180 (4), 932-937.

Langsrud, S., Sidhu, M. S., Heir, E., \&Holck, A. L.(2003).Bacterial disinfectant resistance-a challenge for the food industry.International Journal of Biodeterioration and Biodegradation.51 (4) 283-290.http://dx.org/10.1016/S0964-8305(03)00039-8

Lawrence, J. R., Delaquis, P. J., Korber, D. R., \&Cadwell, D. E.(1987). Behaviour of Pseudomonasfluoresence within the hydrodynamic boundary layer of surface microenvironment.Microbial Ecology. 14, 1-14.

Lawrence, J. R., Kobber, D. R., Hoyle, B. D., Costerton, J. W, \&Cadwell, D. E.(1991). Optical Sectioning of Microbial Biofilms.Journal of Bacteriology. 173 (20), 6558-6567.

LeChevallier, M. W., \&Au, K.-K.(2004). Inactivation and disinfection processes InWater Treatment and Pathogen Control Process Efficiency in Achieving Safe Drinking Water. (pp 41-65). London WHO, IWA Publication.

Lenntech Disinfectants Hydrogen peroxide. Retrieved November 12, 2011, from http://www.lenntech.com/processes/disinfection/chemical/disinfectants-hydrogen-peroxide.ht $\mathrm{m}$.

Lillard, H. S., \&Thomson, J. E.(1983).Efficacy of Hydrogen Peroxide in Poultry Chiller water.Journal of Food Science. 48(1),125-126.http://dx.doi.org/10.1111/j.1365-2621.1983.tb14804.x

Lück, E., \& Jager M.(1997). Other preservatives Hydrogen peroxide In Antimicrobial Food Additives Characteristics, Uses, Effects. Second Revised and Enlarged Edition. Translated from German by Laichena S.F (pp 228-230) Berlin: Springer.

Mahapatra, A. K., Muthukumarappan, K., \&Julson J. L.(2005). Application of Ozone, Bacteriocins and Irradiation in Food Processing: A Review. Critical Reviews in Food Science and Nutrition. 45 (6), 447-461.

Mackay, W. G., Gribbon, L. T., Barer, M. R.,\& Reid, D. C.(1999). Biofilms in drinking water systems: a possible reservoir for Helicobacter pylori. Journal of Applied Microbiology.85, 52S-59S. 
Marrao, G., Verissimo, A., Bowker, R. G., \&Dacosta, M. S. (1993). Biofilm is a major source of Legionella spp. in hydrothermal areas and their dispersion into stream water. FEMS Microbiology Ecology. 12(1),25-33.

Mcdougal, D., \&Kjellberg, S.(2006). Adaptive Responses of VibriosInThompson S. L., Austin, B. \& Swings, J. (eds.) et al., (Eds).The Biology of Vibrios. (pp. 133-155).Washington D.C. ASM Press.

Momba, M. N. B., Kfir, R.,Venter, S. N.,\&Cloete, T. E.(2000).An overview of biofilm formation in distribution systems and its impact on the deterioration of water quality.Water SA 26 (1), 59-66.

Momba, M. N. B., Ndaliso, S.,\&Binda, M. A.(2002). Inhibition of Biofilm regrowth in Potable Water Systems. Water Research Commission.Report No. 1023/1/02.Republic of South Africa.

Momba, M.N.B., \&Binda, M.A. (2002). Combining chlorination and chloramination processes for the inhibition of biofilm formation in drinking surface water system models. Journal of Applied Microbiology. 92, 641-648.

Mueller, R. S.,McDougald, D.,Cusumano, D., Sodhi, N., Kjelleberg, S., Azam, F., \&Bartlett, D. H.(2007). Vibriocholerae Strains Possess Multiple Strategies for Abiotic and Biotic Surfaces Colonization. Journal of Bacteriology.189, (14) 5348-5360. http://dx.org/10:1128/JB.01867.06.

O'Toole,G., Kaplan H. B., \&Kolter, R.(2000). Biofilm Formation as Microbial Development.Annual Review of Microbiology. 54, 49-79.

Palmer, J., Flint, S.,\& Brooks, J.(2007). Bacterial cell attachment, the beginning of a biofilm.Journal of Indian Microbiology and. Biotechnology. 34 (9), 577-588.http://dx.doi.org/10.1007/s10295.007.0234.4

Pericone, C. D., Overweg, K., Hermans, P. W., \&Weiser, J. N.(2000). Inhibitory and bactericidal Effects of Hydrogen Peroxide Production by Streptococcus pneumonia on Other Inhabitants of the Upper Respiratory Tract. Infection and. Immunity. 68 (7),3990-3997. http://dx.doi.org/10.1128/IAI.68.7.3990-3997.2000

Prigent-Combaret, C.,\&Lejeune P.(1999).Monitoring gene expression in biofilms.Methods inEnzymology. 310, 56-79.

Ray, B.(2003). Control of Microorganisms in Foods.InStern R.A, \&Kaplan, L (eds.) Fundamental Food Microbiology ( $3^{\text {rd }}$ ed.). (pp 439-534).London : CRC.

Ray, B., \&Bhunia,A.(2008). Microbial Foodborne Diseases Opportunistic Pathogens, Parasite, and Algal Toxins.InFundamental Food Microbiology (4th edn.)(pp. 315-347). London: CRC.

Reisner, A., Krogfelt, K. A., Klein,B. M., Zechner, E. L., \&Molin, S. (2006). In Vitro Biofilm Formation of Commensal and Pathogenic Escherichia coli Strains: Impact on Environmental and Genetic factors. Journal of Bacteriology. 188(10),3572-3581. http://dx.doi.org/10.1128/JB.188.10.3572-3581.2006

Roncel, M, Navarro, J. A., \&De La Rosa, M. A.(1989).Coupling of solar Energy to Hydrogen Peroxide Production in the CyanobacteriumAnacystisnidulans.Applied and EnvironmentalMicrobiology.55 (22), 483-487.

Schumb, W. C., Scatterfield, C. N., \&Wentworth, R. L.(1955).Hydrogen peroxide.London: Rheinhold Publishing Corporation, Chapman \& Hall Ltd. 
Shikongo-Nambabi, M. N. N.N., Kachigunda, B., \&Venter, S. N.(2010). Evaluation of oxidising disinfectants to control Vibrio biofilms in treated seawater used for fish processing. Water (SA), 36 (3), 215-219.

Sias, R.(2003). Biological Organisms reduction With Hydrogen peroxide.Controlled Environments Magazine. Retrieved November 25, 2011, from http://www.cemag.us/article/biological-organism-reduction-hydrogen-peroxide

Vasconcellos, J. A.(2004a). Food Plant Sanitation: Good Manufacturing Practice Audits. InQuality Assurance for the Food Industry A Practical Approach. (pp 201-263). Washington D.C., Florida: CRC Press, LLC.

Vasconcellos, J. A.(2004b). Hazard Analysis and Critical Control Points. In Quality Assurance for the Food Industry A Practical Approach. (pp 289-298) Washington D.C., Florida: CRC Press, LLC.

Walker, R.(1978). Disinfection and Fluoridation. In: Water supply, Treatment and Distribution. New Jersey 07632: Prentice Hall, Inc.

Wang, W., Ye, B., Yang, L., Li, Y.\&Wang, Y.(2007).Risk assessment on disinfection by-products of drinking water of different water sources and disinfection processes.EnvironmentalInternational. 33 (2),219-225.

Ward, D. R.(2002). HACCP in the Fisheries industry InBremner, H. A. (Ed.) Safety and Quality Issues in fish processing.(pp 5-17) Cambridge, New York:Woodhead Publishing Ltd, CRC Press.

Watts, R. J., Foget, M. K., Kong, S.-H., \&Teel, A. L.(1999).Hydrogen peroxide decomposition in model subsurface systems.Journal of Hazardous Materials, B69 (2), 229-243.

Wekell, M. M., Manger, R., Kolburn, K., Adams, A.,\& Hill, W.(1994). Microbiological quality of Seafoods: viruses, bacteria and parasites. InShahidi F., \&Botta R. J (Eds). Seafoods Chemistry, Processing Technology and Quality.(pp 220-232). Glasgow: Chapman \& Hall.

Whiteley, M., Bangera, M. G., Bumgarner, R. E., Parsek, M R. G., Teitzel, M., Lory, S., P \&Greenberg, E. P. (2001).Gene expression in Pseudomonas aeruginosa biofilms.Letters toNature. 413, 860-864.

Worley, J. L.(2000). Evaluation of Dechlorinating agents and Disposable Containers for odorTesting of Drinking Water. M. Sc. Thesis, Virginia Polytechnic Institute and State University, USA.

\section{Copyright Disclaimer}

Copyright reserved by the author(s).

This article is an open-access article distributed under the terms and conditions of the CreativeCommons Attribution license (http://creativecommons.org/licenses/by/3.0/). 